\title{
Climate-driven limnological changes determine ecological thresholds in an alpine lake
}

\author{
Tomi P. Luoto ${ }^{1,2, *}$, Liisa Nevalainen ${ }^{1,3}$ \\ ${ }^{1}$ Research Institute for Limnology, University of Innsbruck, 5310 Mondsee, Austria \\ ${ }^{2}$ Department of Geosciences and Geography, University of Helsinki, 00014 University of Helsinki, Finland \\ ${ }^{3}$ Department of Environmental Sciences, University of Helsinki, 15140 Lahti, Finland
}

\begin{abstract}
The consequences of climate warming may be dramatic in lakes because changes in surface heating can affect physical and biological processes. We examined sedimentary remains of Cladocera and Chironomidae from a climatically sensitive lake in the Austrian Alps to test the hypothesis that changes in surface water temperature cause direct and indirect shifts in species composition. Contrary to the expectation that oxygen availability in lakes generally decreases under climate warming, our records showed that the assemblages experienced a succession towards a state with increased oxygen availability. Among the benthic fauna, an ecological threshold was crossed around the year 1850, when taxa tolerant of low oxygen concentrations disappeared and oxyphilous taxa began to dominate. In the zooplankton community, the keystone grazer Daphnia was replaced by Bosmina. These ecological changes, especially during the past $20 \mathrm{yr}$, were most likely caused by improved oxygen conditions following the decrease in depth of the thermocline. As the faunal succession was strongly correlated with alpine air temperature trends, the change in thermocline depth has likely been driven by the increasing air temperatures, which have caused warming of the epilimnion and consequently, in combination with windinduced mixing, deepening of the thermocline. These recent changes occur alongside further increasing alpine temperatures and may be reflected in further deepening of the thermocline. We conclude that, in addition to direct climate influences, changes in summer stratification and mixing depth may cause significant changes in aquatic community compositions through changes in oxygen availability under the present climate warming conditions.
\end{abstract}

KEY WORDS: Austrian Alps $\cdot$ Chironomidae Cladocera $\cdot$ Climate change $\cdot$ Little Ice Age Mixing depth

Resale or republication not permitted without written consent of the publisher

\section{INTRODUCTION}

Thermal stratification is crucial for physical, chemical, and biological processes in lakes (Brönmark \& Hansson 2005), with deepening of the thermocline causing shifts in the structure and composition of aquatic communities (Cantin et al. 2011). Typical consequences of altered thermocline depth include changes in internal nutrient loading and phytoplankton abundances (Hambright et al. 1994), which can influence the whole lake ecosystem. In climate change scenarios, a change in thermocline depth is expected in stratified lakes, but its direction remains unclear (Sommaruga et al. 1999, Cantin et al. 2011). Deeper thermoclines can form through declines in dissolved organic carbon (DOC) following increased temperatures and longer periods of drought and subsequent decrease in surface runoff that reduce the input of organic matter (Fee et al. 1996, Schindler et al. 1996). Consequently, deeper thermoclines and deeper vertical mixing would likely lead to improved oxygen conditions in the hypolimnion (Scully et al. 2000). There is also a possibility that climate warming will cause shallowing of the thermocline through 
increased epilimnetic temperatures that would lead to more stratified lakes with shallower thermoclines (DeStasio et al. 1996, Straile et al. 2003). The shallow thermocline location and increased volume of water below the thermocline can potentially cause a decline in hypolimnetic dissolved oxygen (Blumberg \& Di Toro 1990).

Zooplankton and benthos, such as Cladocera and Chironomidae, are key components of aquatic ecosystems (Einarsson \& Örnólfsdóttir 2004, Jeppesen et al. 2011, Raunio et al. 2011). Their intralake distribution is strongly related to abiotic and biotic factors that have relationships with thermocline depth (Leibold 1990, Pinel-Alloul 1995). For studies related to global change biology, fossil assemblages and paleolimnological methods provide a unique and invaluable source of information through the long-term perspective of ecosystem dynamics that cannot be resolved from monitoring data, which usually consist of only a few years or decades of monitoring (Smol 1991, Smol et al. 2005). In the present study, we examined fossil remains of Cladocera and Chironomidae from a sediment core covering the past $300 \mathrm{yr}$ in an alpine lake, the Twenger Almsee, in the Niedere Tauern Alps, Austria, with the hypothesis that recent changes in surface water temperatures have caused direct and indirect shifts in species composition. Our study organisms represent the benthic and planktonic components of the high alpine aquatic ecosystem. The Twenger Almsee is considered to be climatically ultra-sensitive, because its epilimnetic water temperature during summer is anomalously high compared to other Niedere Tauern lakes at the same altitude (Thompson et al. 2005). In our study, we aimed to answer the question: Does the warming climate and subsequent warming of epilimnetic waters cause an increase in warm-adapted species, or is it a faunal change related to indirect effects of a warming water column through a changed thermocline position that may, potentially, cause ambiguous community assemblages?

\section{MATERIALS AND METHODS}

\section{Study site}

The Twenger Almsee $\left(47^{\circ} 13^{\prime} 13^{\prime \prime} \mathrm{N}, 13^{\circ} 36^{\prime} 05^{\prime \prime} \mathrm{E}\right)$ is a pristine lake located in the southern slopes of the Niedere Tauern Alps, Austria, at an altitude of $2118 \mathrm{~m}$ a.s.l. (Fig. 1). The Niedere (Schladminger) Tauern forms a compact but imposing massif of crystalline and limestone bedrock. The small catchment
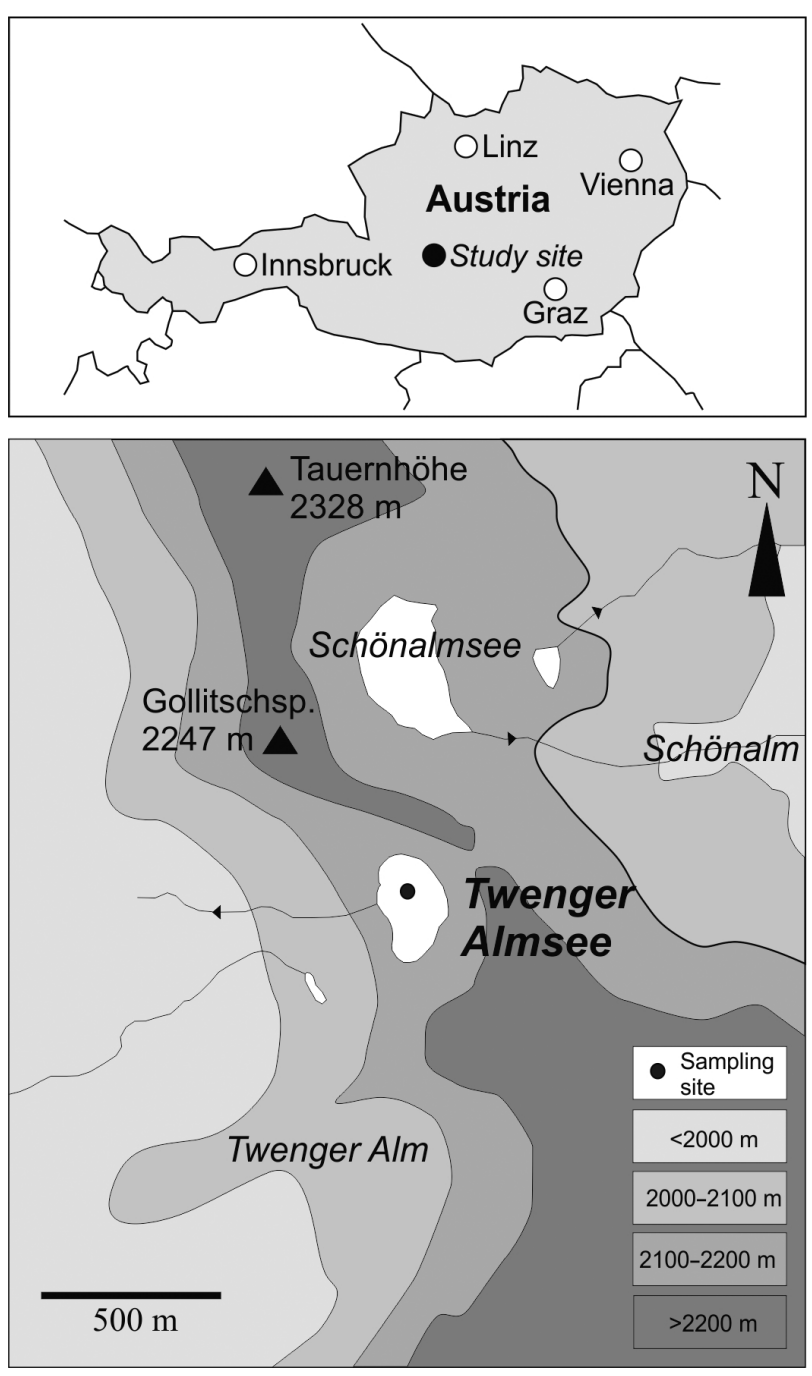

Fig. 1. Study site: the Twenger Almsee in the Niedere Tauern Alps, Austria

of the Twenger Almsee is characterized by rocky cliffs with mica-schists and metamorphic carbonates and alpine meadows with grasses. The lake is located above the active alpine pastures and the current treeline, which is formed by Pinus cembra. Similar to other lakes in the area (Zick et al. 2007), the Twenger Almsee is inhabited by Arctic charr Salvelinus alpinus. These fish originate from 15th and 16th century stockings, and since then, no stocking has taken place (Zick et al. 2007). No aquatic vegetation is present in the lake. The lake has no inlet, and water input is mostly due to direct surface runoff, while the share of groundwater input is relatively small. A small outlet is located on the western side of the basin. The surface area of the alkaline (autumnal epilimnetic $\mathrm{pH}$ 8.3) and oligotrophic (autumnal epi- 
limnetic total phosphorus $3.4 \mu \mathrm{g} \mathrm{l^{-1 }}$, chlorophyll [chl] a $0.5 \mathrm{~g} \mathrm{l}^{-1}$ ) lake is $3.11 \mathrm{ha}$, and maximum depth of the steadily steepening basin is $33.6 \mathrm{~m}$. The Twenger Almsee is a stratified lake (Schmidt et al. 2004), with a deep summer chlorophyll maximum and the threshold $+4^{\circ} \mathrm{C}$ located at $\sim 18 \mathrm{~m}$ (Fig. 2). The depth of the thermocline is season-specific and was located at $\sim 10 \mathrm{~m}$ in late August 2011 (Fig. 2). The dates of autumn and spring mixing, together with the duration of ice cover and mean August water temperatures, are given in Table 1. More details about the study site can be found in Kamenik et al. (2001) and Schmidt et al. (2004).

\section{Sediment sampling and analyses}

A $22 \mathrm{~cm}$ sediment core consisting of homogeneous gyttja was taken on 14 July 2010 from a location where the water depth was $18 \mathrm{~m}$ with a Kajak gravity corer. The sampling site was selected to be close to the present-day deep-water chlorophyll maximum and the depth at which water temperature reaches $4^{\circ} \mathrm{C}$ (Fig. 2), because of the environmental sensitivity of the location (Burnett et al. 2006). The position of the metalimnetic phytoplankton biomass peak (chl a) is closely related to the depth of the thermocline (Burnett et al. 2006). With a deeper thermocline, this peak can be found deeper in the water column because its position is largely determined by density changes in the water column (Cantin et al. 2011). In

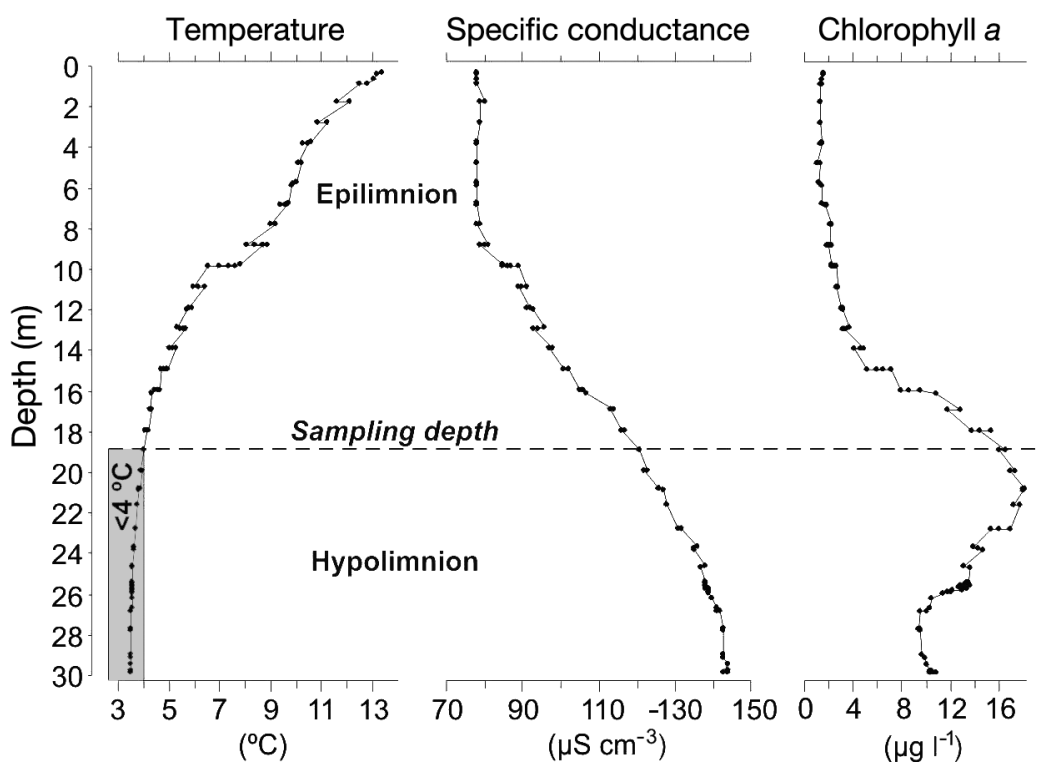

Fig. 2. Profiles of temperature, specific conductance, and chl $a$ in the Twenger Almsee measured on 22 August 2011
Table 1. Calendar days of autumn and spring mixing and duration of ice cover in the Twenger Almsee in the Niedere Tauern Alps, Austria. nd: no data

\begin{tabular}{|cccc|}
\hline Year & $\begin{array}{c}\text { Calendar day of } \\
\text { autumn mixing }\end{array}$ & $\begin{array}{c}\text { Calendar day of } \\
\text { spring mixing }\end{array}$ & $\begin{array}{c}\text { Duration of } \\
\text { ice cover (d) }\end{array}$ \\
\hline 1998 & 302 & nd & 240 \\
1999 & nd & 177 & nd \\
2009 & 289 & nd & 250 \\
2010 & 300 & 174 & 221 \\
2011 & nd & 156 & nd \\
\hline
\end{tabular}

the Twenger Almsee, the summer chl a peak is located between depths of 21 and $23 \mathrm{~m}$, i.e. below the thermocline (Fig. 2). In part, the depth of the phytoplankton peak in alpine lakes is related to their UV radiation avoidance, but also to the higher nutrient availability in the hypolimnion (Saros et al. 2005), which is reflected in the increased specific conductance towards the deeper areas of the lake (Fig. 2). The lower limit of the phytoplankton peak is determined by light penetration. The collected sediment sequence was subsampled at $1 \mathrm{~cm}$ intervals, and the samples were stored in a cold room at $+4^{\circ} \mathrm{C}$.

The procedures for the microfossil analyses followed the standard protocols described by Brooks et al. (2007) and Szeroczyńska \& Sarmaja-Korjonen (2007), on which the fossil identifications were also based. A minimum counting sum that has been found adequate for statistical community analyses (Heiri \& Lotter 2001, Larocque 2001, Quinlan \& Smol 2001a, Kurek et al. 2010, Nevalainen 2010) was set at 50 individuals for both chironomid and cladoceran samples. Magnetic susceptibility was measured using a Bartington Instruments equipment sensor MS2C. To determine organic content of the sediment, loss on ignition (LOI) was assessed from wet sediment using a sample size of approximately $10 \mathrm{~g}$. The samples were dried at $105^{\circ} \mathrm{C}$ for $12 \mathrm{~h}$ and ignited at $550^{\circ} \mathrm{C}$ for $2 \mathrm{~h}$ (Dean 1974 , Heiri et al. 2001).

\section{Sediment dating}

The samples from the sediment core were analyzed for ${ }^{210} \mathrm{~Pb}$ activity to provide a chronology (Fig. 3). The analyses were done in the Laboratory of Quaternary Geochronology, Insti- 


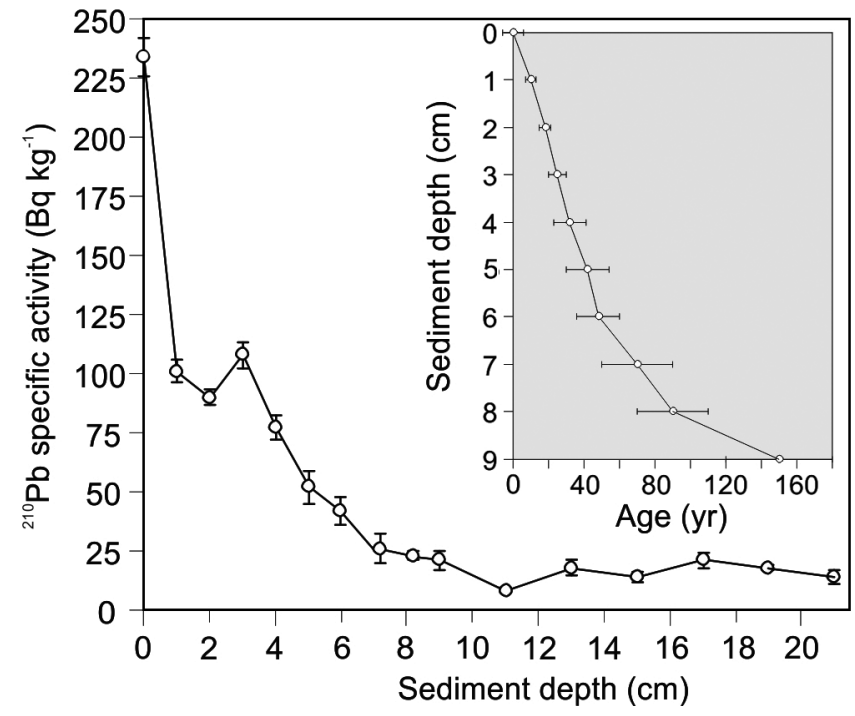

Fig. 3. Total specific activity of ${ }^{210} \mathrm{~Pb}$ in the sediment profile of the Twenger Almsee and the associated age-depth model

tute of Geological Sciences, Polish Academy of Sciences in Warsaw, Poland. ${ }^{210} \mathrm{~Pb}$ activity of the sediments was determined indirectly via alpha-spectrometry measuring the ${ }^{210} \mathrm{Po}(\alpha=5.31 \mathrm{MeV}, \mathrm{T} 1 / 2=$ $138 \mathrm{~d}$ ) activity (Flynn 1968). The ${ }^{210} \mathrm{Po}$ is generated by the decay of ${ }^{210} \mathrm{~Pb}$, and then ${ }^{210} \mathrm{Bi}$ and is assumed to be in equilibrium with the parent isotopes. As an internal yield tracer, the known amount of ${ }^{208}$ Po was added to the weighted sample. Po was separated from the sample using strong hydrochloric and nitric acid and was deposited on silver disks (Flynn 1968). Activity of ${ }^{210} \mathrm{Po}$ and ${ }^{208} \mathrm{Po}$ was measured using an OCTETE PC alpha spectrometer produced by ORTEC. The constant rate of unsupported ${ }^{210} \mathrm{~Pb}$ supply model was used to calculate sediment age (Appleby 2001). This model assumes a variable sedimentation rate, sediment compaction and mixing. Activity of unsupported (allochthonous) ${ }^{210} \mathrm{~Pb}$ was calculated by subtraction of supported (autogenic) ${ }^{210} \mathrm{~Pb}$ activity. Supported ${ }^{210} \mathrm{~Pb}$ was determined by measurements of old sediments, which contain no allochthonous ${ }^{210} \mathrm{~Pb}$, and assumed constant activity of autogenic ${ }^{210} \mathrm{~Pb}$ along the sediment column. The age-depth function was calculated using a randomization method, and the curve was fitted using the LOESS procedure (Cleveland \& Devlin 1988). The lower part of the sediment core was obtained through extrapolation of the sedimentation rates in the upper part of the core. Because no plant macrofossils were found and there was not enough chitinous material available, we were not able to use radiocarbon dating to validate the chronology in the lower part of the core. Furthermore, as the lake is situated on calcareous bedrock, bulk sediment samples would be unsuitable and unreliable for radiocarbon dating at this site. Hence, caution should be taken in the age interpretations of the lower part of the core. Due to this uncertainty, in this paper, we discuss the pre-1850 AD period collectively and avoid any within-period interpretations.

\section{Data analyses}

Detrended correspondence analysis (DCA) was applied to determine gradient lengths of primary faunal compositional axes to determine whether to use linear or unimodal methods in further analyses. Consequently, linear methods and principal component analysis (PCA) were used to detect variability in the invertebrate assemblages. The DCA and PCAs were performed on square-rooted relative taxa abundances using downweighting of rare species and run with the program CANOCO v.4.52 (ter Braak \& Šmilauer 2002). The benthic quality ratio (BQI) (Wiederholm 1980) was applied to the Chironomidae assemblages to describe the ecological quality of the benthic environment. The BQI can vary from 0 (no chironomids $=$ permanently anoxic) to 5 (ultraoligotrophic and well oxygenated). In addition, we applied the ratio between the abundance of cladocerans Acroperus harpae ('good') and Alona affinis ('moderate') to describe the developments in the limnological status of the lake (Luoto et al. 2012).

The general annual Northern Hemisphere temperature data, reconstructed (tree-ring based) and instrumentally observed by D'Arrigo et al. (2006), were applied to describe climate variability during the time coverage of the sediment core. In addition, the instrumental data by Auer et al. (2007) were used for illustrating alpine winter and annual temperature variability. The temperature data were obtained through the World Data Center for Paleoclimatology and NOAA's National Climatic Data Center, Paleoclimatology Branch website (www.ncdc.noaa.gov/ paleo/paleo.html) and through the HISTALP (historical instrumental climatological surface time series of the greater Alpine region) website (www.zamg.ac.at/ histalp/). The time resolutions in the temperature data were adjusted to lower resolution to match the present chronology. Relationships between different biological scores (PCA axis 1, BQI, and ratio of Acroperus harpae to Alona affinis), sediment properties (magnetic susceptibility and LOI), and Northern Hemisphere temperatures were examined using 
Pearson correlations (r), and relationships were considered significant at $\mathrm{p} \leq 0.01$. A potential error source is associated with the correlations calculated between the parameters from the core data and the temperature data due to the poor chronological control of the lower part of the core. However, all core parameters as well as the temperature data showed constantly low values for the pre-1850 period that may indicate that the risk of misinterpretation and erroneous correlation calculations are relatively minor.

\section{RESULTS}

A total of 17 Chironomidae and 5 Cladocera taxa were identified from the sediment profile of the Twenger Almsee. For the Cladocera, the minimum counting sum of 50 individuals was not achieved in the lowermost sediment samples $(21-10 \mathrm{~cm})$ due to the scarcity of the remains. The most abundant chironomids were Micropsectra radialis-type (18 occurrences; mean abundance $34.7 \%$; maximum abundance $83.6 \%)$, Sergentia $(21 ; 26.0 \%$; $60 \%)$, and Procladius $(21 ; 22.4 \% ; 60.8 \%)$, whereas the most abundant cladocerans were Chydorus sphaericustype $(22 ; 26.3 \% ; 79.3 \%)$, Alona affinis $(22 ; 24.3 \%$;
$55.6 \%)$, Daphnia pulex-type $(21 ; 24.1 \% ; 62.5 \%)$, and Bosmina longispina $(17 ; 22.6 \% ; 65.4 \%)$. Of the chironomids, Procladius and Sergentia dominated the assemblages from the bottom of the core ( 1700 AD) until $\sim 1850$, and Zavrelimyia was also common (Fig. 4). From 1850 onwards, M. radialis-type dominated, and Paratanytarsus austriacus-type was also common. Paracladius and Heterotrissocladius marcidus-type increased their abundances during the most recent decades. Of the cladocerans, D. pulextype and $A$. affinis showed progressively declining trends in their abundances from 1700 to the present, while $B$. longispina showed an increasing trend (Fig. 5). Around 1850, A. harpae appeared in the sequence and remained common until the present. C. sphaericus s.l. was common throughout the sequence but showed a distinct peak in its abundance near the top of the core $(\sim 2000$ AD) when $B$. longispina simultaneously declined.

The DCA of chironomid assemblages showed gradient lengths of 2.196 and 1.587 SD for axis 1 and 2, respectively, and the DCA of cladoceran assemblages showed gradient lengths of 1.571 and 0.702 $\mathrm{SD}$, indicating that linear methods, such as PCA, were most appropriate for further analyses. PCA axis 1 scores for both chironomids and cladocerans showed a succession from low values in the early part

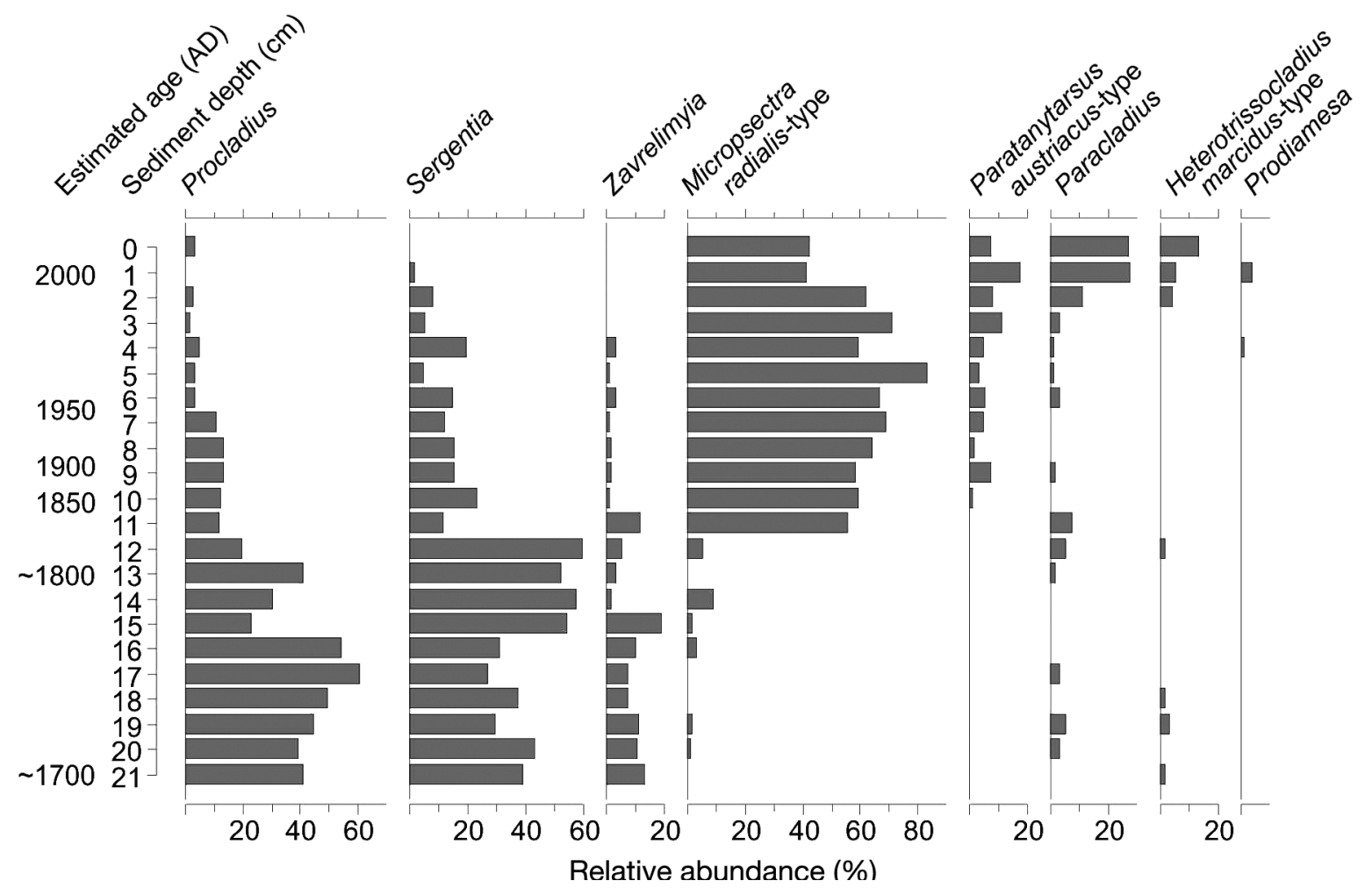

Fig. 4. Chironomidae assemblages in the sediment profile of the Twenger Almsee 

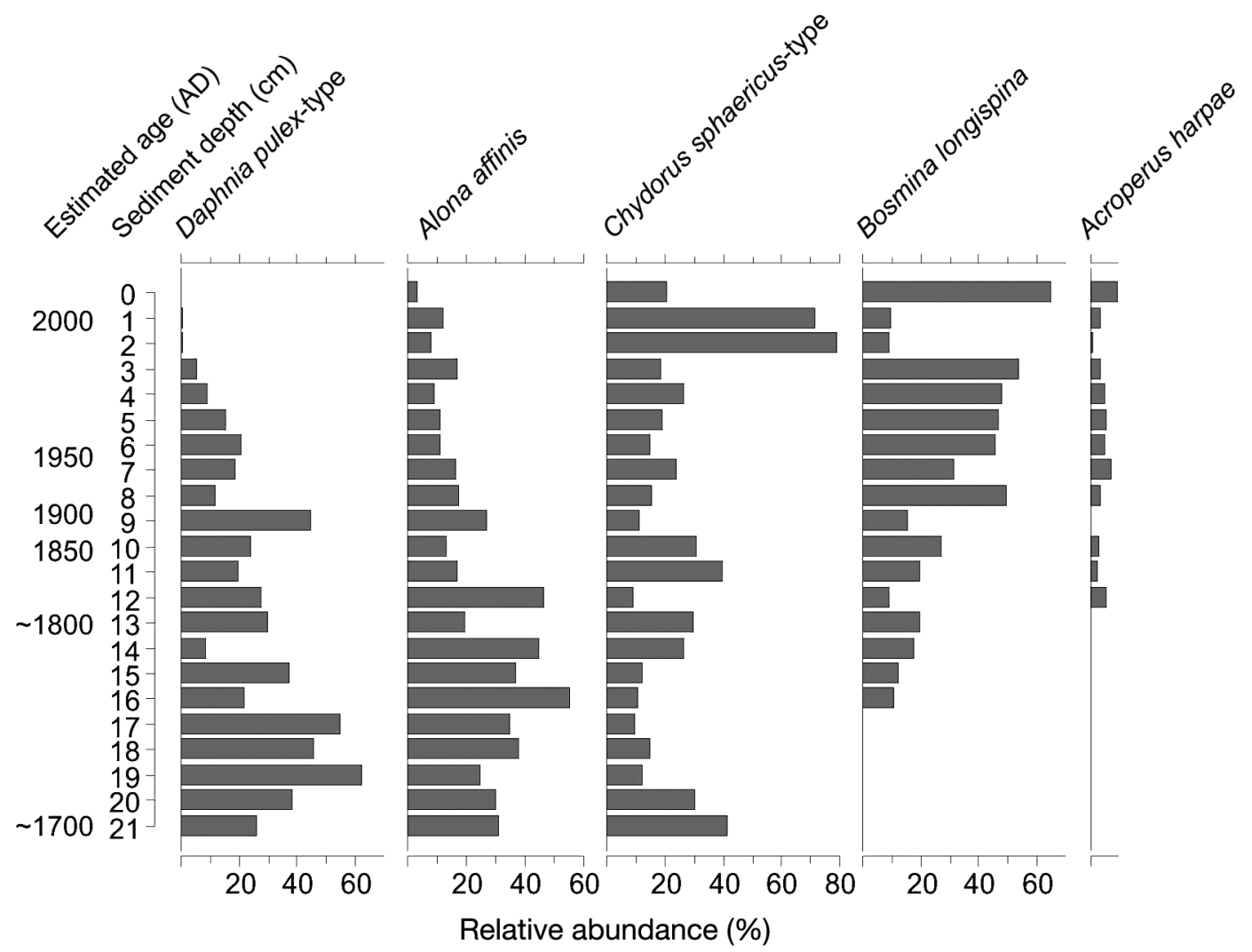

Fig. 5. Cladocera assemblages in the sediment profile of the Twenger Almsee
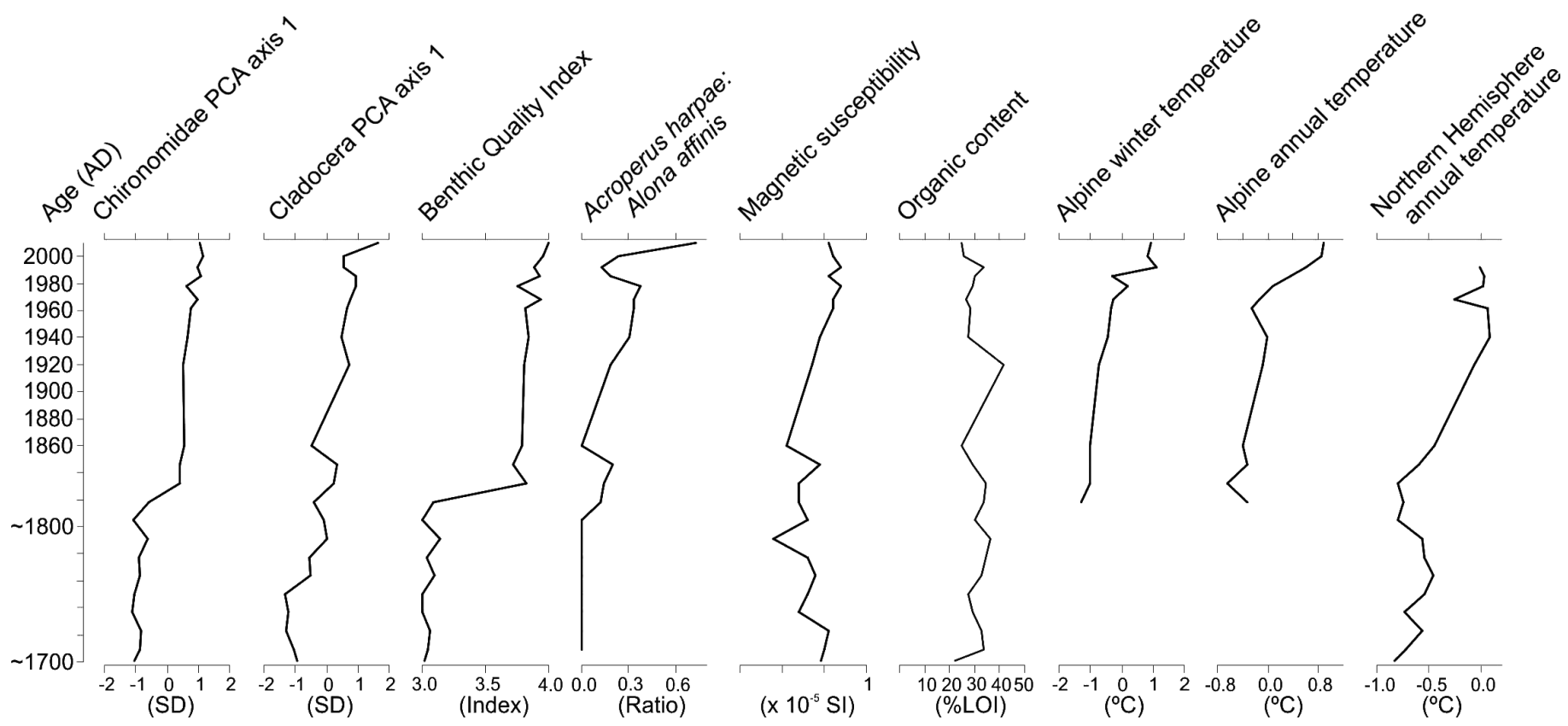

Fig. 6. Principal component analysis (PCA) axis 1 scores for Chironomidae and Cladocera, benthic quality index (BQI), ratio between Acroperus harpae and Alona affinis, magnetic susceptibility, and organic content (LOI: loss on ignition) of the sediment in the Twenger Almsee compared with instrumental alpine winter and annual temperatures (Auer et al. 2007) and reconstructed/instrumentally observed Northern Hemisphere annual temperatures (D'Arrigo et al. 2006) 
Table 2. Pearson correlation matrix. Correlations are significant at ${ }^{*} \mathrm{p} \leq 0.05,{ }^{* *} \mathrm{p} \leq 0.01$. PCA1: principal component analysis axis 1, BQI: benthic quality index, DCA1: detrended correspondence analysis axis 1

\begin{tabular}{|c|c|c|c|c|c|c|c|}
\hline & $\begin{array}{c}\text { Chironomidae } \\
\text { DCA1 }\end{array}$ & $\begin{array}{l}\text { Cladocera } \\
\text { DCA1 }\end{array}$ & BQI & $\begin{array}{c}\text { A. harpae: } \\
\text { A. affinis }\end{array}$ & $\begin{array}{l}\text { Reconstructed } \\
\text { temperature }\end{array}$ & $\begin{array}{c}\text { Magnetic } \\
\text { susceptibility }\end{array}$ & $\begin{array}{l}\text { Organic } \\
\text { content }\end{array}$ \\
\hline Chironomidae PCA1 & $1^{* *}$ & & & & & & \\
\hline Cladocera PCA1 & $0.86^{* *}$ & $1^{* *}$ & & & & & \\
\hline BQI & $0.99^{* *}$ & $0.86^{* *}$ & $1^{* *}$ & & & & \\
\hline Acroperus harpae : Alona affinis & $0.73^{* *}$ & $0.83^{* *}$ & $0.73^{* *}$ & $1^{* *}$ & & & \\
\hline Reconstructed temperature & $0.77^{* *}$ & $0.73^{* *}$ & $0.74^{* *}$ & $0.72^{* *}$ & $1^{* *}$ & & \\
\hline Magnetic susceptibility & $0.47^{*}$ & 0.41 & $0.43^{*}$ & $0.52^{*}$ & $0.54^{*}$ & $1^{* *}$ & \\
\hline Organic content & 0.11 & 0.00 & 0.11 & 0.24 & 0.11 & 0.24 & $1^{* *}$ \\
\hline
\end{tabular}

of sediment core towards high values in the recent samples (Fig. 6). The BQI was $\sim 3$ between $\sim 1700$ and $\sim 1850 \mathrm{AD}$ and then increased to $\sim 4$ until the present, when it reached its highest values (Fig. 6). A similar trend was observed in the ratio of Acroperus harpae to Alona affinis ratio. No clear trends were observed in the LOI values, but magnetic susceptibility showed an increase from 1850 onwards (Fig. 6). All biological scores correlated strongly ( $r=0.70$ to 0.93 ) and significantly $(\mathrm{p} \leq 0.01)$ with the reconstructed Northern Hemisphere temperatures (Table 2). Magnetic susceptibility showed moderate correlation with all parameters, except with cladoceran PCA axis 1 , whereas the organic content of the sediment failed to have any significant correlation in the record.

\section{DISCUSSION}

The early part of the sediment core from the Twenger Almsee, prior to $\sim 1850$, was characterized by a chironomid community composed of Procladius, Sergentia, and Zavrelimyia (Fig. 4). Procladius and Sergentia are known to tolerate low oxygen concentrations and even anoxia (Quinlan \& Smol 2001b, Heiri \& Lotter 2003, Luoto \& Nevalainen 2011). Sergentia possesses hemoglobin, which enables it to tolerate oxygen depletion (Walker 1991), while larvae of Procladius, and also Zavrelimyia, are free-living predators (Brooks et al. 2007) that can temporarily migrate away from the low-oxygen/anoxic areas, if necessary. The extent of oxygen depletion depends on several factors, probably the most important being thermocline depth and ice-cover duration (Blumberg \& Di Toro 1990). Therefore, it is likely that during this time interval, the thermocline was located in relatively shallow water in the lake and that the sampling point at a depth of $18 \mathrm{~m}$ was located below the mixing depth in the hypolimnion. At the same time, before $\sim 1850$, the cladoceran community was domi- nated by Daphnia pulex-type and Alona affinis (Fig. 5). D. pulex-type is a planktonic taxon, which can tolerate anoxia through its vertical migration (Weider 1984, Nesbitt et al. 1996, Dodson et al. 1997), whereas $A$. affinis can occur in the shallow and deep habitats of lakes (Nevalainen 2011, 2012). It must be noted, however, that the representativeness of the Cladocera communities in our records may be hampered by the fact that less than 50 individuals were encountered from the samples between 21 and $10 \mathrm{~cm}$ (pre-1850). The ${ }^{210} \mathrm{~Pb}$ chronology estimates that the sediments below $9 \mathrm{~cm}$ sediment depth, in which the remains were scarce, were accumulated before $\sim 1850$, coinciding with the Little Ice Age (LIA) (D'Arrigo et al. 2006; Fig. 6). Therefore, the extremely harsh climate conditions most likely reduced zooplankton success, resulting in low frequency of the remains in this sediment section (cf. Manca \& Comoli 1995). Nevertheless, in lakes with low species richness, such as the Twenger Almsee, even a very low counting sum is likely to be adequate for describing the general Cladocera community composition (Nevalainen 2010).

During the LIA, European summer and winter temperatures were strongly decreased (Bradley \& Jones 1993, Jones \& Briffa 2001, Luoto et al. 2009), and this cold period is also evident from the European alpine paleorecords (Larocque-Tobler et al. 2012, Trachsel et al. 2012). Cool summers were likely reflected in epilimnetic water temperatures and stratification patterns during the ice-free season causing shallowing of the depth of the thermocline, and the long ice-covered period probably prevented winter-time hypolimnetic oxygenation of the Twenger Almsee. Consequently, it is possible that internal loading from the release of nutrients from the anoxic sediments (Auer et al. 1993, Sondergaard et al. 2001) during the LIA caused nutrient enrichment and oxygen depletion in the hypolimnion. This interpretation is in agreement with the preference of the dominating 
chironomids Procladius and Sergentia for low-oxygen and high-nutrient lakes (Luoto 2011).

From 1850 onwards, the ultraoligotrophic and oxyphilous Micropsectra radialis-type (Brooks et al. 2007, Luoto 2011) began to dominate following the rapid decline in the abundance of Procladius, Sergentia, and Zavrelimyia (Fig. 4). In addition, Paratanytarsus austriacus-type, which is also an oligotrophic taxon (Brooks et al. 2007) and is a typical inhabitant of the Niedere Tauern lakes (Luoto 2012, Luoto \& Nevalainen 2012, Nevalainen \& Luoto 2012), appeared in the sequence. With the cladocerans, the community change around 1850 was more subtle (Fig. 5). However, clear shifts occurred in the community (Fig. 6) as Daphnia pulex-type and Alona affinis decreased with the simultaneous increase in Bosmina longispina. In addition, oligotrophic Acroperus harpae (Bos \& Cumming 2003) appeared in the sequence. A. harpae is usually characterized as a phytophilous species (Fryer 1968, Whiteside et al. 1978), and in the Italian and Swiss alpine lakes, $A$. harpae has been observed to be strongly associated with potassium (Nevalainen et al. 2011), which is related to aquatic vegetation (Nicholls et al. 1996). However, as aquatic vegetation was not observed in our study lake, it cannot be the environmental factor driving the increase in A. harpae. Nevertheless, these faunal changes, reflected as increases in BQI and in the ratio of $A$. harpae to A. affinis (Fig. 6), indicate increased concentrations of dissolved oxygen; furthermore, these changes were strongly correlated with increased air temperatures (Table 2, Fig. 6). Therefore, it is possible that the warming climate changed the lake's stratification as water temperature increased and the ice-covered period became shorter. In addition to the influence of increasing epilimnetic temperatures in summer in deepening the thermocline (e.g. Schindler et al. 1996), it is possible that the thermocline deepened following the longer ice-free period, which allowed greater mixing of the water column due to increased effects of wind-induced turbulence. The general summertime position of the thermocline depth must have deepened below the sampling depth so that the oxyphilic Micropsectra radialis-type could have succeeded at the depth of the sampling point. According to an analysis of synoptic survey data of European alpine lakes, Procladius, which declined in the Twenger Almsee, and $M$. radialis, which increased, are species that segregate mainly according to the sediment organic matter, a variable closely related to lake productivity and oxygen availability (Catalan et al. 2009). Further evidence for the fact that the chironomids were indeed responding to changes in stratification and not directly to air temperatures is provided by the cold temperature optimum of M. radialis-type (Brooks \& Birks 2000, Luoto 2009); the increased temperatures should have caused a general decrease in the abundance of $M$. radialis-type if the influence of temperature was direct. This also indicates that problems arise when using fossil chironomids as paleoclimatic proxies in lakes that have undergone changes in their mixing depth. In fact, a recent study from Canada demonstrated that chironomid assemblages are strongly influenced by climate-mediated thermal regimes in lakes (Quinlan et al. 2012). Catalan et al. (2009) showed that the cladocerans Daphnia and Bosmina in European alpine lakes have an opposite response to ice-cover length, with Daphnia preferring a shorter and Bosmina a longer ice-free period that could instead imply a direct influence of warmed epilimnetic waters on the planktonic taxa.

The low-oxygen tolerant chironomids further decreased during the 20th century, while the oxyphilic chironomids Paracladius and Heterotrissocladius marcidus-type (Moller Pillot \& Buskens 1990, Luoto \& Salonen 2010) increased during the most recent decades (Fig. 4). Furthermore, the BQI continued increasing slightly toward the present (Fig. 6). These faunal trends may reflect enhanced mixing of the lake during summers. Furthermore, oxygen depletion also often occurs during the ice-covered period in high alpine lakes (Ohlendorf et al. 2000), and as climate warming typically leads to a shorter duration of ice cover, the time of oxygen depletion decreases and oxygen levels may thus increase with warming. The duration of the rather short growing season would increase along with a decrease in ice-cover duration and, as a consequence, seasonal growth of phytoplankton and interactions with zooplankton would also change.

In the cladoceran community, Daphnia pulex-type and Alona affinis showed progressively declining trends in their abundances (Fig. 5). Daphnia is very sensitive to fish predation in clear-water alpine lakes (Cammarano \& Manca 1997) and is known to use vertical migration and the hypolimnion below the thermocline as a refuge to avoid visual fish predators (Wright \& Shapiro 1990, Hartleb \& Haney 1998). However, it is unlikely that fish stocking has taken place in the area since medieval times (Zick et al. 2007), and the present Arctic charr population, therefore, originates from the 15th and 16th centuries. Previous studies have confirmed that Daphnia is sensitive to changes in mixing depth and water temperature (Fischer et al. 2011). Both mixing depth and 
water temperature are closely related to air temperatures but also to precipitation. Therefore, changes in lake depth are also a potential influence on biotic changes, not only in the littoral and profundal areas, but also around the thermocline. However, the biotic assemblages in the Twenger Almsee are composed of taxa typical of deep lakes, and there is no clear evidence to suggest any direct effects of changes in lake depth on these assemblages. Furthermore, alpine lakes in general have shown an increase in DOC with warming (Sommaruga et al. 1999), over longer time scales (Schmidt et al. 2008), that may explain part of the faunal changes observed in our study, but there is no direct evidence for this.

Chydorus sphaericus-type was common through the sediment profile but showed a sudden increase in its relative abundance around the year 2000 with a simultaneous decline in Bosmina longispina. However, due to the taxonomic plurality and ubiquitous nature of C. sphaericus-type (Frey 1980), it is very difficult to determine the factors responsible for this change. On the other hand, the occurrence of Bosmina in the Austrian Alps is related to a specific climatic threshold and thus it can be used as a climate proxy (Kamenik et al. 2007). In our records, the abundance of $B$. longispina corresponded with the calculated air temperatures (Table 2); B. longispina appeared at the end of the LIA and became dominant around 1900 (Fig. 4), when the temperatures further increased (Fig. 6). The short-lived decline in the abundance of $B$. longispina in the late 20th century also corresponded with the slight decline in alpine annual temperatures (Fig. 6), hence suggesting a direct response of this planktonic species to air temperature. Furthermore, if Daphnia declined as a response to fish predation under deepening of the thermocline and its predation refuge, an available niche for Bosmina may have emerged for it to colonize, and this succession may have been further emphasized by climate warming. Moreover, deepening of the thermocline and vertical mixing makes deep water areas more available for epilimnetic plankton species, including $B$. longispina (Nykänen et al. 2009), because nutrient concentrations are usually higher in deeper parts of lakes (Kristensen et al. 1992; our Fig. 2).

In the present study, the organic content of the sediment showed no distinct change over the examined time period (Fig. 6), suggesting that the trophic status probably did not change and that faunal trends were indeed driven by changes in the oxygen regime, most likely through climate forcing. The organic content remained relatively high for an alpine lake, most likely due to the deepness of the sampling site. This is because the organic content is strongly related to water depth in the Niedere Tauern lakes (Luoto 2012). Further evidence that productivity did not change is provided by the magnetic susceptibility results, which show an increase along with climate warming (Fig. 6). Magnetic susceptibility is sensitive to climate changes (Geiss et al. 2003, Luoto et al. 2008) and also to changes in thermocline depth (Anderson et al. 2005). Magnetic susceptibility in lake sediments largely depends on the input and abundance of magnetic particles, mostly ironbearing minerals (Dearing 1999), thus indicating changes in processes in the catchment. Due to the extremely steep topography, the Twenger Almsee is above the modern and historical cattle pastures and direct human influence that could influence the lake trophic status. Therefore, the simultaneous changes in faunal assemblages and magnetic susceptibility were probably climate driven through thermocline and/or erosional changes and hence are most likely unrelated to any change in the lake's trophic status.

Previous studies have shown that changes in water quality, stratification, and circulation patterns can be climate-driven (DeStasio et al. 1996, Schmidt et al. 1998, King et al. 1999, Quinlan et al. 2012). Although the Twenger Almsee has gone through a complete faunal turnover during the past centuries, the aquatic communities are likely to experience major changes in the future following the warming of epilimnetic waters. These potential future ecosystem changes will be, at least partly, indirectly forced by the present climate warming through altered limnological stratification. Following the rapidly increased temperatures in the Alps during the past decades, several key taxa, such as Sergentia, Zavrelimyia, and Daphnia, have already disappeared from our sampling site in the Twenger Almsee and have been replaced by new taxa, such as Heterotrissocladius marcidus-type and Bosmina longispina.

\section{CONCLUSIONS}

Our study shows that cold-adapted/oxyphilous species have increased in the Twenger Almsee over the past 2 centuries, with the ecological turnover at around 1850 probably caused mainly by indirect, rather than direct, effects of climate change. The critical thresholds for faunal turnovers were apparently determined by the summer mixing depth and by the duration of the ice-covered period. During the LIA, long ice-covered periods prevailed, and the summertime thermocline was probably shallow, causing 
hypolimnetic oxygen deficiency and allowing the invertebrates that can survive in anoxic conditions to dominate in the lake. After 1850, the deepening of the thermocline due to increased epilimetic water temperatures and the longer ice-free period following an increase in air temperature apparently caused the improvement in lake water quality and led to the increase in oxyphilous taxa. Our record also suggests that major ecological changes have occurred in the Twenger Almsee over the most recent decades. Under the present conditions of climate warming, it appears that, in addition to direct climate influences, indirect climate-driven limnological change, such as changes in the depth of the thermocline, the length of the ice-free period and consequent changes in oxygen availability, may influence alpine lake ecosystems, leading to changes in species distribution and dominance.

Acknowledgements. We thank J. Knoll for help with the fieldwork and for preparing the chironomid and cladoceran samples and R. Kurmayer for help with the fieldwork and environmental data. This study is a contribution of the DETECTIVE (DEcadal deTECTion of biodIVErsity in alpine lakes) project of the Austrian Academy of Sciences managed by R. Kurmayer and T. Weisse. Personal funding was provided by the Academy of Finland (the ILMAVEIVI project, grant no: 250343) to T.P.L. and by the Kone Foundation (the EGGER project - Sedimentary EGG banks as indicators of EnviRonmental Change) to L.N. We are grateful to the 3 reviewers and C. Burns for constructive comments that helped to improve the value of this paper.

\section{LITERATURE CITED}

Anderson L, Abbott MB, Finney BP, Edwards ME (2005) Palaeohydrology of the Southwest Yukon Territory, Canada, based on multiproxy analyses of lake sediment cores from a depth transect. Holocene 15:1172-1183

Appleby PG (2001) Chronostratigraphic techniques in recent sediments. In: Last WM, Smol JP (eds) Tracking environmental changes using lake sediments. Vol 1: Basin analysis, coring, and chronological techniques. Kluwer Academic, Dordrecht, p 171-203

> Auer MT, Johnson NA, Penn MR, Effler SW (1993) Measurement and verification of rates of sediment phosphorus release for a hypereutrophic urban lake. Hydrobiologia 253:301-309

> Auer I, Böhm R, Jurkovic A, Lipa W and others (2007) HISTALP - historical instrumental climatological surface time series of the greater Alpine region 1760-2003. Int J Climatol 27:17-46

Blumberg AF, Di Toro DC (1990) Effects of climate warming on dissolved oxygen concentrations in Lake Erie. Trans Am Fish Soc 119:210-223

Bos DG, Cumming BF (2003) Sedimentary cladoceran remains and their relationship to nutrients and other limnological variables in 53 lakes from British Columbia, Canada. Can J Fish Aquat Sci 60:1177-1189
Bradley RS, Jones PD (1993) 'Little Ice Age' summer temperature variations: their nature and relevance to recent global warming trends. Holocene 3:367-376

Brönmark C, Hansson LA (2005) The biology of lakes and ponds. Oxford University Press, Oxford

Brooks SJ, Birks HJB (2000) Chironomid-inferred late-glacial and early-Holocene mean July air temperatures for Kråkenes Lake, western Norway. J Paleolimnol 23:77-89

Brooks SJ, Langdon PG, Heiri O (2007) The identification and use of Palaeoarctic Chironomidae larvae in palaeoecology. QRA Technical Guide No. 10. Quaternary Research Association, London

Burnett L, Moorhead D, Hawes I, Howard-Williams C (2006) Environmental factors associated with deep chlorophyll maxima in dry valley lakes, South Victoria Land, Antarctica. Arct Antarct Alp Res 38:179-189

Cammarano P, Manca M (1997) Studies on zooplankton in two acidified high mountain lakes in the Alps. Hydrobiologia 356:97-109

> Cantin A, Beisner BE, Gunn JM, Prairie YT, Winter JG (2011) Effects of thermocline deepening on lake plankton communities. Can J Fish Aquat Sci 68:260-276

> Catalan J, Barbieri MG, Bartumeus F, Bitušík P and others (2009) Ecological thresholds in European alpine lakes. Freshw Biol 54:2494-2517

Cleveland WS, Devlin SJ (1988) Locally-weighted regression: an approach to regression analysis by local fitting. J Am Stat Assoc 83:596-610

D'Arrigo R, Wilson R, Jacoby G (2006) On the long-term context for late twentieth century warming. J Geophys Res 111:D03103, doi:10.1029/2005JD006352

Dean WE (1974) Determination of carbonate and organic matter in calcareous sediments and sedimentary rocks by loss on ignition: comparison with other methods. J Sediment Petrol 44:242-248

Dearing J (1999) Magnetic susceptibility. In: Walden J, Oldfield F, Smith JP (eds) Environmental magnetism: a practical guide. Technical Guide 6. Quaternary Research Association, London, p 5-34

> DeStasio BT Jr, Hill DK, Kleinhans JM, Nibbelink NP, Magnuson JJ (1996) Potential effects of global climate change on small north-temperate lakes: physics, fish, and plankton. Limnol Oceanogr 41:1136-1149

Dodson SI, Tollrian R, Lampert W (1997) Daphnia swimming behaviour during vertical migration. J Plankton Res 19: 969-978

Einarsson Á, Örnólfsdóttir EB (2004) Long-term changes in benthic Cladocera populations in Lake Myvatn, Iceland. Aquat Ecol 38:253-262

> Fee EJ, Hecky RE, Kasian SEM, Cruikshank DR (1996) Effects of lake size, water clarity, and climatic variability on mixing depths in Canadian Shield lakes. Limnol Oceanogr 41:912-920

Fischer JM, Olson MH, Williamson CE, Everhart JC and others (2011) Implications of climate change for Daphnia in alpine lakes: predictions from long-term dynamics, spatial distribution, and a short-term experiment. Hydrobiologia 676:263-277

Flynn WW (1968) The determination of low-levels of polonium-210 in environmental materials. Anal Chim Acta 43:221-226

Frey DG (1980) On the plurality of Chydorus sphaericus (O. F. Müller) (Cladocera, Chydoridae), and designation of a neotype from Sjaelsø, Denmark. Hydrobiologia 69: 83-123 
Fryer G (1968) Evolution and adaptive radiation in the Chydoridae (Crustacea: Cladocera): a study in comparative functional morphology and ecology. Philos Trans R Soc Lond B Biol Sci 254:221-384

Geiss CE, Umbanhowar CE, Camil P, Banerjee SK (2003) Sediment magnetic properties reveal Holocene climate change along the Minnesota prairie-forest ecotone. J Paleolimnol 30:151-166

> Hambright KD, Gophen M, Serruya S (1994) Influence of long-term climatic changes on the stratification of a subtropical, warm monomictic lake. Limnol Oceanogr 39: 1233-1242

> Hartleb CF, Haney JF (1998) Use of a thermal and light refugium by Daphnia and its effects on foraging pumpkinseeds. Environ Biol Fishes 51:339-349

Heiri O, Lotter AF (2001) Effect of low count sums on quantitative environmental reconstructions: an example using subfossil chironomids. J Paleolimnol 26:343-350

Heiri O, Lotter AF (2003) 9000 years of chironomid assemblage dynamics in an Alpine lake: long-term trends, sensitivity to disturbance, and resilience of the fauna. J Paleolimnol 30:273-289

> Heiri O, Lotter AF, Lemcke G (2001) Loss on ignition as a method for estimating organic and carbonate content in sediments: reproducibility and comparability of results. J Paleolimnol 25:101-110

> Jeppesen E, Nõges P, Davidson T, Haberman J and others (2011) Zooplankton as indicators in lakes: a scientificbased plea for including zooplankton in the ecological quality assessment of lakes according to the European Water Framework Directive (WFD). Hydrobiologia 676: 279-297

> Jones PD, Briffa KR (2001) The 'Little Ice Age': local and global perspectives. Clim Change 48:5-8

Kamenik C, Schmidt R, Kum G, Psenner R (2001) The influence of catchment characteristics on the water chemistry of mountain lakes. Arct Antarct Alp Res 33:404-409

Kamenik C, Szeroczyńska K, Schmidt R (2007) Relationships among recent Alpine Cladocera remains and their environment: implications for climate-change studies. Hydrobiologia 594:33-46

King JR, Shuter BJ, Zimmerman AP (1999) Signals of climate trends and extreme events in the thermal stratification pattern of multibasin Lake Opeongo, Ontario. Can J Fish Aquat Sci 56:847-852

> Kristensen P, Søndergaard M, Jeppesen E (1992) Resuspension in a shallow eutrophic lake. Hydrobiologia 228: 101-109

Kurek J, Korosi JB, Jeziorski A, Smol JP (2010) Establishing reliable minimum count sizes for cladoceran subfossils sampled from lake sediments. J Paleolimnol 44:603-612

Larocque I (2001) How many chironomid head capsules are enough? A statistical approach to determine sample size for palaeoclimatological reconstructions. Palaeogeogr Palaeoclimatol Palaeoecol 172:133-142

> Larocque-Tobler I, Stewart MM, Quinlan R, Trachsel M, Kamenik C, Grosjean M (2012) A last millennium temperature reconstruction using chironomids preserved in sediments of anoxic Seebergsee (Switzerland): a consensus at local, regional and Central European scales. Quat Sci Rev 41:49-56

- Leibold MA (1990) Resources and predators can affect the vertical distributions of zooplankton. Limnol Oceanogr 35:938-944

> Luoto TP (2009) Subfossil Chironomidae (Insecta: Diptera) along a latitudinal gradient in Finland: development of a new temperature inference model. J Quat Sci 24: $150-158$

> Luoto TP (2011) Indicator value of midge larvae (Diptera: Nematocera) in shallow boreal lakes with a focus on habitat, water quality, and climate. Aquat Insects 33: $351-370$

> Luoto TP (2012) Intra-lake patterns of aquatic insect and mite remains. J Paleolimnol 47:141-157

> Luoto TP, Nevalainen L (2011) Inferring reference conditions of hypolimnetic oxygen for deteriorated Lake Mallusjärvi in the cultural landscape of Mallusjoki, southern Finland using fossil midge assemblages. Water Air Soil Pollut 217:663-675

> Luoto TP, Nevalainen L (2012) Ecological responses of aquatic invertebrates to climate change over the past $\sim 400$ years in a climatically ultra-sensitive lake in the Niedere Tauern Alps (Austria). Fundam Appl Limnol 181:169-181

Luoto TP, Salonen VP (2010) Fossil midge larvae (Diptera: Chironomidae) as quantitative indicators of late-winter hypolimnetic oxygen in southern Finland: a calibration model, case studies and potentialities. Boreal Environ Res 15:1-18

Luoto TP, Nevalainen L, Sarmaja-Korjonen K (2008) Multiproxy evidence for the 'Little Ice Age' from Lake Hampträsk, southern Finland. J Paleolimnol 40:1097-1113

> Luoto TP, Sarmaja-Korjonen K, Nevalainen L, Kauppila T (2009) A 700 year record of temperature and nutrient changes in a small eutrophied lake in southern Finland. Holocene 19:1063-1072

Luoto TP, Nevalainen L, Sarmaja-Korjonen K (2012) Zooplankton (Cladocera) in assessments of biologic integrity and reference conditions: application of sedimentary assemblages from shallow boreal lakes. Hydrobiologia, doi:10.1007/s10750-012-1422-4

> Manca M, Comoli P (1995) Temporal variations of fossil Cladocera in the sediments of Lake Orta (N. Italy) over the last 400 years. J Paleolimnol 14:113-122

Moller Pillot HKM, Buskens RFM (1990) De larven der Nederlandse Chironomidae (Diptera): autoecologie en verspreiding. Nederlandse Faunistische Mededelingen 1c, 1-85

Nesbitt LM, Riessen HP, Ramcharan CW (1996) Opposing predation pressures and induced vertical migration responses in Daphnia. Limnol Oceanogr 41:1306-1311

Nevalainen L (2010) Evaluation of microcrustacean (Cladocera, Chydoridae) biodiversity based on sweep net and surface sediment samples. Ecoscience 17:356-364

Nevalainen L (2011) Intra-lake heterogeneity of sedimentary cladoceran (Crustacea) assemblages forced by local hydrology. Hydrobiologia 676:9-22

> Nevalainen L (2012) Distribution of benthic microcrustaceans along a water depth gradient in an Austrian Alpine lake - sedimentary evidence for niche separation. Limnologica 42:65-71

Nevalainen L, Luoto TP (2012) Faunal (Chironomidae, Cladocera) responses to post-Little Ice Age climate warming in the high Austrian Alps. J Paleolimnol 48: 711-724

> Nevalainen L, Luoto TP, Levine S, Manca M (2011) Modern and pre-Industrial Age distributions of Cladocera in Italian and Swiss Alpine lakes. Hydrobiologia 676:173-185

Nicholls KH, Michalski MFP, Gibson W (1996) An experimental demonstration of trophic interactions affecting 
water quality of Rice Lake, Ontario (Canada). Hydrobiologia 319:73-85

Nykänen M, Vakkilainen $K$, Liukkonen M, Kairesalo T (2009) Cladoceran remains in lake sediments: a comparison between plankton counts and sediment records. J Paleolimnol 42:551-570

Ohlendorf C, Bigler C, Goudsmit GH, Lemcke G and others (2000) Causes and effects of long periods of ice cover on a remote high Alpine lake. J Limnol 59:65-80

Pinel-Alloul B (1995) Spatial heterogeneity as a multiscale characteristic of zooplankton community. Hydrobiologia 300-301:17-42

$>$ Quinlan R, Smol JP (2001a) Setting minimum head capsule abundance criteria in chironomid-based inference models. J Paleolimnol 26:327-342

Quinlan R, Smol JP (2001b) Chironomid-based inference models for estimating end-of-summer hypolimnetic oxygen from south-central Ontario shield lakes. Freshw Biol 46:1529-1551

- Quinlan R, Paterson MJ, Smol JP (2012) Climate-mediated changes in small lakes inferred from midge assemblages: the influence of thermal regime and lake depth. J Paleolimnol 48:297-310

Raunio J, Heino J, Paasivirta L (2011) Non-biting midges in biodiversity conservation and environmental assessment: findings from boreal freshwater ecosystems. Ecol Indic 11:1057-1064

Saros JE, Interlandi SJ, Douyle S, Michel TJ, Williamson CE (2005) Are the deep chlorophyll maxima in alpine lakes primarily induced by nutrient availability, not UV avoidance? Arct Antarct Alp Res 37:557-563

Schindler DW, Bayley SE, Parker BR, Beaty KG and others (1996) The effects of climatic warming on the properties of boreal lakes and streams at the Experimental Lakes Area, northwestern Ontario. Limnol Oceanogr 41: 1004-1017

Schmidt R, Wunsam S, Brosch U, Fott J and others (1998) Late and post-glacial history of meromictic Längsee (Austria), in respect to climate change and anthropogenic impact. Aquat Sci 60:56-88

Schmidt R, Kamenik K, Lange-Bertalot H, Klee R (2004) Fragilaria and Staurosira (Bacillariophyceae) from sediment surfaces of 40 lakes in the Austrian Alps in relation to environmental variables, and their potential for palaeoclimatology. J Limnol 63:171-189

Schmidt R, Roth M, Tessadri R, Weckström K (2008) Disentangling late-Holocene climate and land use impacts on an Austrian alpine lake using seasonal temperature anomalies, ice-cover, sedimentology, and pollen tracers. J Paleolimnol 40:453-469

Scully NM, Leavitt PR, Carpenter SR (2000) Century-long effects of forest harvest on the physical structure and

Editorial responsibility: Carolyn Burns,

Dunedin, New Zealand autotrophic community of a small temperate lake. Can J Fish Aquat Sci 57:50-59

Smol JP (1991) Are we building enough bridges between paleolimnology and aquatic ecology? Hydrobiologia 214: 201-206

Smol JP, Wolfe AP, Birks HJB, Douglas MSV and others (2005) Climate-driven regime shifts in the biological communities of arctic lakes. Proc Natl Acad Sci USA 102: 4397-4402

- Sommaruga R, Psenner R, Schafferer E, Koinig KA, Sommaruga-Wögrath S (1999) Dissolved organic carbon concentration and phytoplankton biomass in high-mountain lakes of the Austrian Alps: potential effect of climatic warming an UV underwater attenuation. Arct Antarct Alp Res 31:247-253

Sondergaard M, Jensen PJ, Jeppesen E (2001) Retention and internal loading of phosphorus in shallow, eutrophic lakes. ScientificWorldJournal 1:427-442

Straile D, Johnk K, Rossknecht H (2003) Complex effects of winter warming on the physicochemical characteristics of a deep lake. Limnol Oceanogr 48:1432-1438

Szeroczyńska K, Sarmaja-Korjonen K (2007) Atlas of subfossil Cladocera from central and northern Europe. Friends of the Lower Vistula Society, Swiecie

ter Braak CJF, Šmilauer P (2002) CANOCO reference manual and CanoDraw for Windows user's guide: software for canonical community ordination (Version 4.5). Microcomputer Power, Ithica

Thompson R, Kamenik C, Schmidt R (2005) Ultra-sensitive Alpine lakes and climate change. J Limnol 64:139-152

Trachsel M, Kamenik C, Grosjean M, McCaroll D and others (2012) Multi-archive summer temperature reconstruction for the European Alps, AD 1053-1996. Quat Sci Rev 46:66-79

> Walker IR (1991) Modern assemblages of arctic and alpine Chironomidae as analogues for late-glacial communities. Hydrobiologia 214:223-227

- Weider LJ (1984) Spatial heterogeneity of Daphnia genotypes: vertical migration and habitat partitioning. Limnol Oceanogr 29:225-235

Whiteside MC, Williams JB, White CP (1978) Seasonal abundance and pattern of chydorids, Cladocera in mud and vegetative habitats. Ecology 59:1177-1188

Wiederholm T (1980) The use of benthos in lake monitoring. J Water Pollut Control Fed 52:537-547

Wright D, Shapiro J (1990) Refuge availability: a key to understanding the summer disappearance of Daphnia. Freshw Biol 24:43-62

Zick D, Gassner H, Rinnerthaler M, Jäger P, Patzner RA (2007) Application of population size structure indices to Arctic charr Salvelinus alpinus (L.) in Alpine lakes in Austria. Ecol Freshw Fish 16:54-63

Submitted: July 6, 2012; Accepted: November 30, 2012

Proofs received from author(s): January 17, 2013 